\title{
Chamber arrangement versus wall structure in the high-rank phylogenetic classification of Foraminifera
}

\author{
Zofia Dubicka \\ Acta Palaeontologica Polonica 64 (1), 2019: 1-18 doi:https://doi.org/10.4202/app.00564.2018
}

Foraminiferal wall micro/ultra-structures of Recent and well-preserved Jurassic (Bathonian) foraminifers of distinct foraminiferal high-rank taxonomic groups, Globothalamea (Rotaliida, Robertinida, and Textulariida), Miliolida, Spirillinata and Lagenata, are presented. Both calcite-cemented agglutinated and entirely calcareous foraminiferal walls have been investigated. Original test ultra-structures of Jurassic foraminifers are given for the first time. "Monocrystalline" wall-type which characterizes the class Spirillinata is documented in high resolution imaging. Globothalamea, Lagenata, porcelaneous representatives of Tubothalamea and Spirillinata display four different major types of wall-structure which may be related to distinct calcification processes. It confirms that these distinct molecular groups evolved separately, probably from single-chambered monothalamids, and independently developed unique wall types. Studied Jurassic simple bilocular taxa, characterized by undivided spiralling or irregular tubes, are composed of miliolid-type needle-shaped crystallites. In turn, spirillinid "monocrystalline" test structure has only been recorded within more complex, multilocular taxa possessing secondary subdivided chambers: Jurassic Paalzowella and Recent Patellina. More integrated molecular and structural studies are needed in order to better understand taxonomic position and phylogeny of tubular taxa. Unilocular and multichambered Lagenata (Lagenidae and Nodosariidae, respectively) show identical test micro and ultra-structure which suggests their close phylogenetic relationship and questions most recent theories of their separate evolutionary history and origins. A comparison of Recent, Cretaceous, and Jurassic foraminiferal test structure indicates that test characteristics at particular higher-rank taxonomic levels change very little over time and thus can serve as good proxies for the taxonomic designations of fossil taxa, when their state of preservation is appropriate for microstructural observations.

Key words: Foraminifera, biomineralisation, test structure, high-rank classification, Jurassic, Poland.

Zofia Dubicka [‥dubicka@uw.edu.pl], University of Warsaw, Faculty of Geology, al. Żwirki i Wigury 93, 02-089 Warszawa, Poland. 
This is an open-access article distributed under the terms of the Creative Commons Attribution License (for details please see creativecommons.org), which permits unrestricted use, distribution, and reproduction in any medium, provided the original author and source are credited.

Farf Full text $(2,430.8 \mathrm{kB})$ 